\title{
REVIEW
}

\section{Feeding ecology of free-living aquatic nematodes}

\author{
Preben Jensen
}

\author{
Sonderforschungsbereich 313 der Universität Kiel, Olshausenstraße 40, D-2300 Kiel, Federal Republic of Germany
}

\begin{abstract}
The buccal cavity structure of free-living aquatic nematodes indicates 4 feeding groups: deposit feeders, epistrate feeders, scavengers and predators. This is in contrast to a previous classification which united omnivores and predators and separated deposit feeders into selective and nonselective groups. The new classification shows that the previous view that heavy predator pressure plays a major role in the structuring of meiobenthic communities has been much overemphasized. Most predatory species in the previous classification are herein recognized as 'garbage collectors', i.e. species with scavenging feeding habits. The actual feeding behaviour of epistrate-feeding species shows that they are able to break open cell membranes of food items in the buccal cavity and suck out the cell contents (juice feeders), in contrast to deposit-feeding species which swallow the whole food item (particulate feeders), indicating different sets of digestive enzymes. Buccal cavity morphology within predators indicates 2 feeding types. Trans-epidermal uptake of dissolved organic matter is suggested as an additional food supply for thiobiotic species (mainly deposit feeders), hence indicating mixotrophy. Size, shape, quality and quantity of food items may to some extent explain coexistence of congeners. Nematode mobility and mucus release may attract potential food or keep food sources in optimal condition, i.e. gardening.
\end{abstract}

\section{INTRODUCTION}

Studies on food and feeding in free-living aquatic nematodes were in the past approached by various methods all concerned with oral feeding. Wieser (1953) classified nematode feeding groups and types according to their buccal cavity structure, i.e. small vs large, and armed with teeth vs unarmed. Results of this analysis on dead animals showed that (1) nematodes have extremely diversified structures related to food ingestion and obviously adapted to a diversified spectrum of food items, and (2) factors other than buccal cavity morphology must operate in order to explain the co-existence of congeneric species. Tietjen and coworkers and Schiemer (reviews in Alongi \& Tietjen 1980, Schiemer 1984) approached nematode feeding through experiments including both quantitative and qualitative aspects. These findings confirmed Wieser's hypothesis that nematodes are highly selective with respect to size, shape and quality of food offered. Selective digestion, i.e. selective enzymatic activity, was shown by Jennings \& Colam (1970) and Jennings $\&$ Deutsch (1975). Deutsch (1978) and Nuss (1985) showed morphological and histochemical differences in the intestinal cells related to food absorption in a varicty of nematodes. Trans-epidermal uptake of dissolved organic matter (DOM: mainly sugars and amino acids) has not yet been shown in free-living aquatic nematodes but has been suggested by Jensen (1986) as an additional food supply in thiobiotic species because of their relatively larger body surface. Finally, there is also some evidence that the considerable mobility of some nematodes (Meyers et al. 1970, Cullen 1973, Warwick 1981) and their release of organic matter (Riemann \& Schrage 1978, Bongers 1983) may attract bacteria and other microbes and maintain them in optimal condition, i.e. gardening. The present paper reviews these findings which are discussed in terms of feeding groups and types, and resource partitioning.

\section{FEEDING GROUPS AND TYPES}

From lateral views of the buccal cavity of fixed specimens Wieser (1953) divided marine nematodes into 4 trophic groups: (1A) selective deposit feeders; 
(1B) non-selective deposit feeders (both groups encompassing species without teeth, and with small and large buccal cavities, respectively); (2A) epistrate feeders; (2B) omnivore-predators. This classification has been widely used since then and adjusted in subsequent years (e.g. Wieser 1960, Wieser \& Kanwisher 1961, Boucher 1973, Platt 1977). Romeyn \& Bouwman (1983) as well as Bouwman ef al. (1984) even go so far as to include the cephalic setation as an additional character of importance in nematode feeding strategy; however, no convincing evidence supports such an inclusion. The arbitrary subdivision of deposit feeders was rejected by Jensen (1986) both because experimental evidence is lacking and because the range of sizes of mouth openings and buccal cavities is as large in other fceding groups as in deposit feeders (Fig. 1).

The present classification separates 4 feeding groups of species concerned with oral feeding. Deposit and
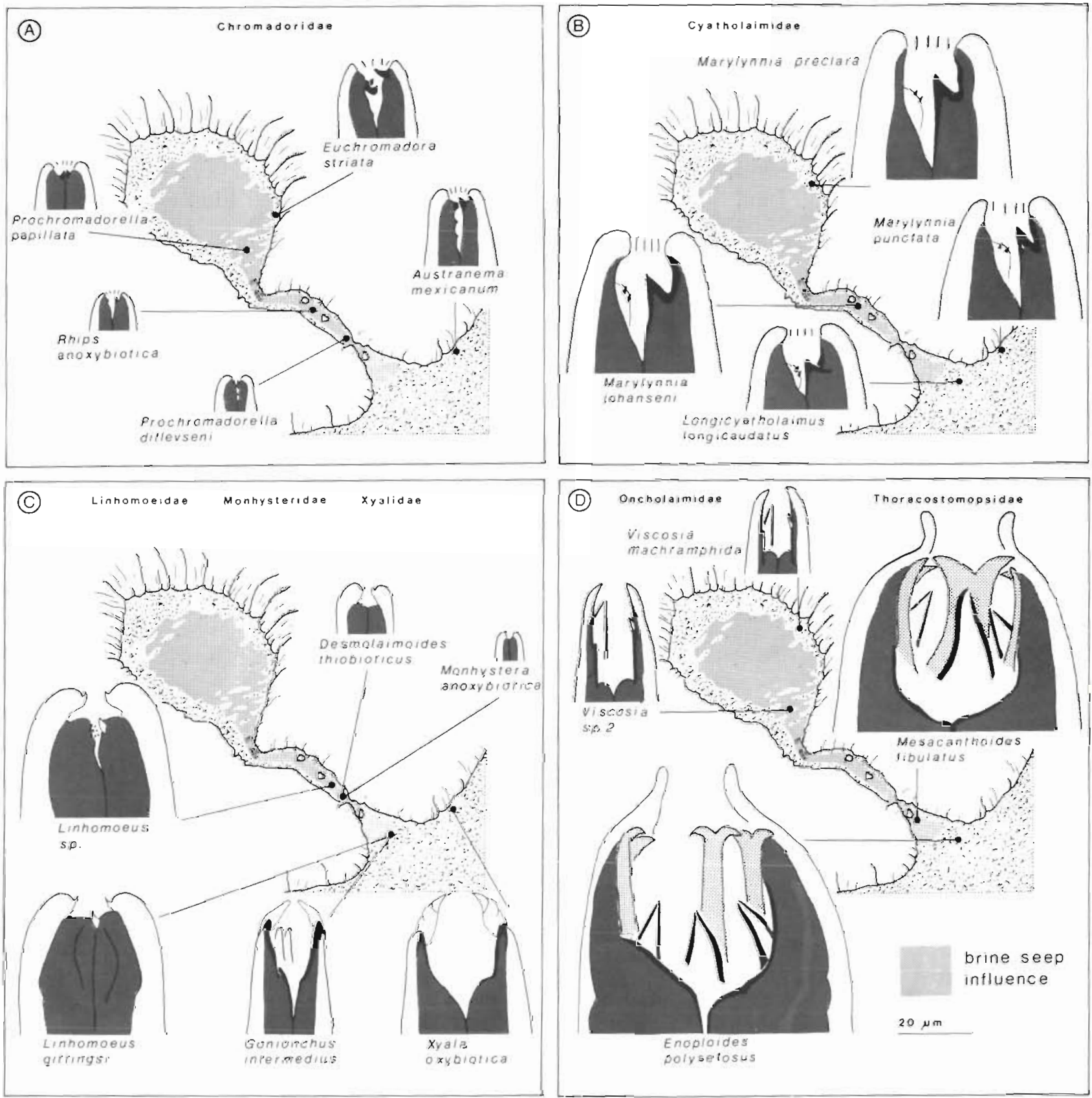

Fig. 1. Location of population maxima, and buccal cavity structure, of most abundant nematodes along an almost $100 \mathrm{~m}$ long horizontal brine seep gradient in the East Flower Garden, NW Gulf of Mexico, at $70 \mathrm{~m}$ depth shown as feeding groups. (A,B) Epistrate feeders. (C) Deposit feeders. (D) Scavengers (Oncholaimidae) and predators (Thoracostomopsidae). Classified into their systematic relationships. All figures are drawn to the same scale in left lateral view. Adapted from Jensen (1986) 
epistrate feeders are distinguished as 2 feeding groups by the absence or presence of a tooth in the buccal cavity, respectively. Consequently, the 2 groups include different feeding types but may exploit the same food source. A third group of species is recognized as scavengers, united by the presence of an onchium (tooth-like structure) in the buccal cavity penetrated by a duct through which the contents of a salivary gland cell empty. Scavengers lack mandibles, claws and articulating plates in the buccal cavity which characterize the fourth group, predators. Finally, trans-epidermal uptake of DOM is likely a significant feeding habit of thiobiotic species (deposit and epistrate feeders), indicating mixotrophy.

\section{Deposit feeders and epistrate feeders}

Few publications exist on the feeding habits of freeliving aquatic nematodes. However, 3 diatom-feeding types are known. Chromadorita tenuis (epistrate feeder) brings the diatom into the buccal cavity (Fig. 2). The 2 valves of the diatom are opened by damaging the girdle with the dorsal tooth and the contents passed to the intestine, where they are found as liquid with lipid droplets (Fig. 3C, D). The empty frustule is then discarded (Fig. 2). The presence of a buccal apparatus in the intestine of a chromadorid should not be taken as an indication of cannibalism as suggested by Allgén (1927) since it may be retained from the preceeding developmental stage (Jensen 1983a). Eudiplogaster pararmatus (epistrate feeder) holds the diatom firmly with the lips. It apparentiy punctures the frustule and swallows the cell contents. The empty frustule is dis- carded (Romeyn et al. 1983). Daptonema biggi (deposit feeder) swallows the whole diatom (Jensen 1979). Romeyn \& Bouwman (1983) give further examples of species feeding, e.g. C. guidoschneideri handles a diatom in the same way as $C$. tenuis does. However, they termed $C$. guidoschneideri a 'cracker' because of the way it breaks the diatom with its teeth. Linhomoeus gittingsi (deposit feeder) feeding on the sulphide-oxidizing bacteria Beggiatoa spp. was suggested by Jensen (1986) to ingest/suck the bacteria into the intestine like spaghetti. A similar observation was made on a small Monhystera species (deposit feeder) ingesting living blue-green bacteria Oscillatoria okeni (Fig. 3A, B) isolated from Potamogeton perfoliatus in the Finnish archipelago.

Deposit feeders and epistrate feeders thus influence microbial densities directly by their grazing on bacteria, fungi and unicellular algae. The considerable mobility of the high numbers of nematodes in microbial loci (Meyers et al. 1970, Jensen 1986), the expansion by their burrows of sites for microbial activities (Cullen 1973, Warwick 1981), their continuous mucus secretion (Riemann \& Schrage 1978, Bongers 1983) and evidence that nematodes may contribute to nutritional recycling (Tietjen 1980) strongly indicate that they maintain microbial populations near exponential state of growth. This is known from the influence of protozoan activities (e.g. Fenchel 1970, Barsdate et al. 1974, Fenchel \& Harrison 1976) and more recent evidence with nematodes (Tenore et al. 1977, Gerlach 1978, Bonni \& Mitchell 1980, Findlay \& Tenore 1982, Pamatmat \& Findlay 1983). The quantity and quality of the nematode's food is thereby maximized; this is gardening in its broadest sense, including the effects of intensified grazing.
Fig. 2. Chromadorita tenuis. Sequence of events when the nematode feeds on the pennate diatom Nitzschia palea var. debilis. Adapted from Jensen (1982)
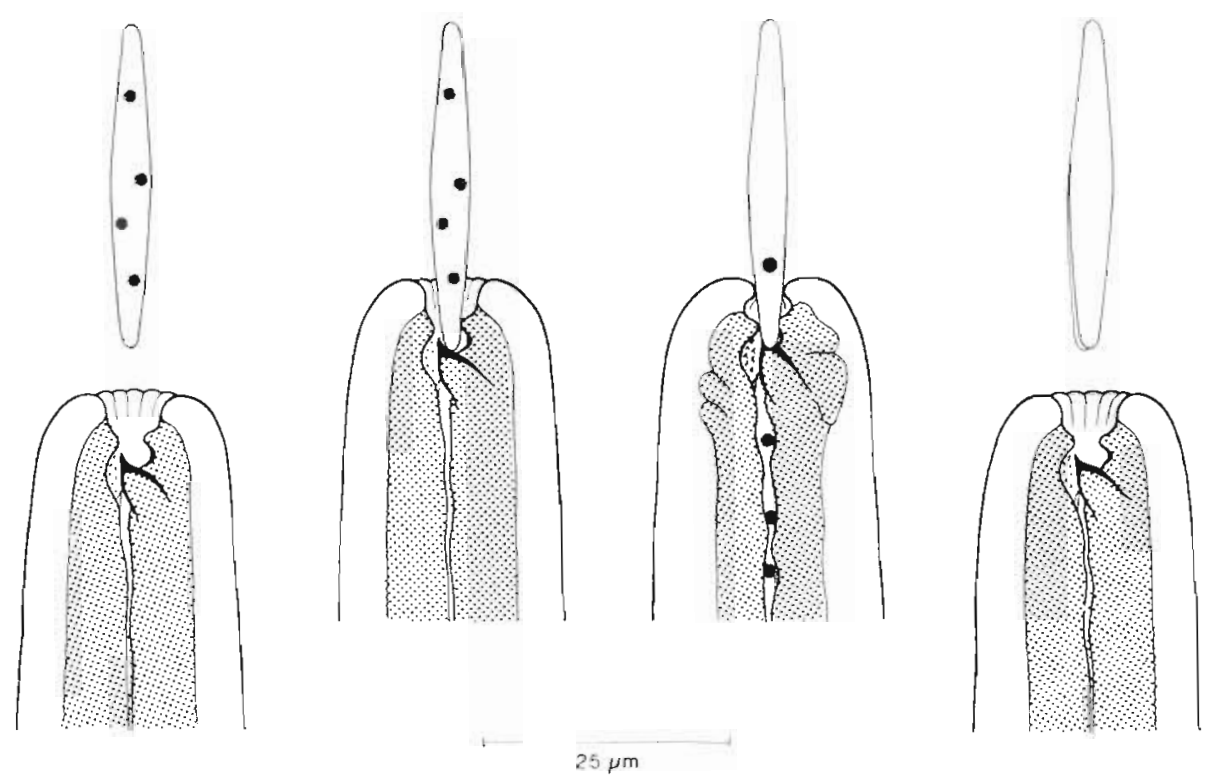

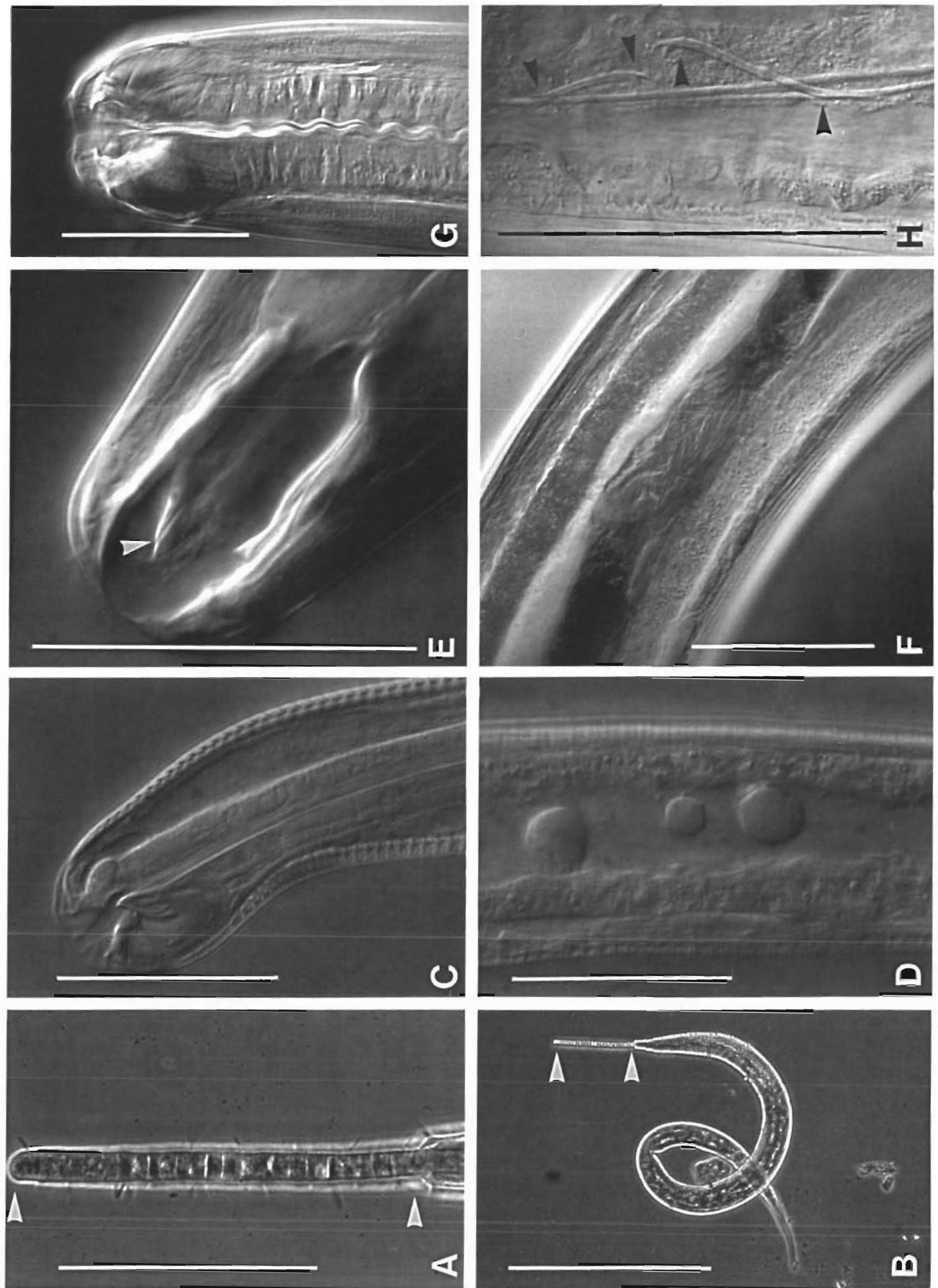


\section{Predators}

Wieser's Group 2B (omnivore-predators) includes firstly, predators which catch their living prey by protrusible claws or mandibles (Thoracostomopsidae, Enoplidae, Selachinematidae; Fig. 1D \& 3G, H); and those which catch the prey with widely open mouth (Sphaerolaimidae), macerating it in the buccal cavity by means of articulating plates or other sclerotizations. Secretions from oesophageal salivary gland cells begin to digest the prey even before it is swallowed, although it may be found in the intestine still in an identifiable shape. Some adult Selachinematidae species lack an anus (Gourbault \& Vincx 1985) indicating a different digestion capacity as compared to Thoracostomopsidae and Enoplidae which have an anus throughout life.

\section{Scavengers}

The remainder of Wieser's Group 2B are the omnivores, previously classified with the predator group (Wieser 1953). The taxa of numerical importance (both in terms of species richness and abundance) are Oncholaimidae and Enchelididae. Wieser's assumption that these are predator species is based on an analogous type of buccal cavity found in the terrestrial mononchs (Mononchidae), which have a voluminous and sclerotized buccal cavity with one or more teeth and denticles. Adult mononchs are known to feed on a large range of living animals (e.g. Thorne 1927 , Nielsen 1949, also confirmed in a more recent study, Grootaert \& Maertens 1976). The predatory similitude is indeed apparent at low magnification and from many drawings of species concerned. However, the tooth (teeth) in mononchs is solid and not penetrated by a duct (Baqri \& Baqri 1983) whereas the large subventral 'tooth' ('teeth') in oncholaimids and enchelidiids is penetrated by a duct emptying subterminally (Fig. 3E). Jennings \& Colam (1970) suggested that the secretions through the ducts penetrating the 2 subventral 'teeth' in Pontonema vulgare yield an active enzyme (esterase) when mixed on discharge.

Results of feeding experiments by Thun (1968) and Romeyn \& Bouwman (1983) on Adoncholaimus

Fig. 3. Buccal cavity structures and gut contents of 4 nematode feeding groups. (A, B) Monhystera $\mathrm{sp}$. (deposit feeder) ingesting a blue-green bacteria Oscillatoria okeni (arrows). (C, D) Chromadorita tenuis (epistrate feeder): (C) buccal cavity; (D) cell juice including lipid droplets in intestine. (E, F) Adoncholaimus thalassophygas (scavenger): (E) buccal cavity showing 'tooth' penetrated by a duct (arrow); ( $F$ ) gut contents. (G, H) Enoplus brevis (predator): (G) buccal cavity; (H) setae (arrows) of Naiididae (Oligochaeta) in intestine. (C, D) from Jensen (1982); others originals. Scale bars: $\mathrm{B}=100 \mu \mathrm{m} ;$ others $=25 \mu \mathrm{m}$ thalassophygas apparently support Wieser's opinion on this species' feeding group and feeding type. They also reported that the buccal cavity is slightly expanded when the prey is swallowed; the prey is punctured by the 'tooth' and its contents sucked out (cf. illustrations in Thun 1968, reproduced in Remmert 1980, Romeyn 1980). Heip et al. (1978) offered live nematodes Panagrellus redivivus to Oncholaimus oxyuris and concluded that $O$. oxyuris is a predator. However, younger juveniles apparently could not survive on the nematode as prey, but were raised on agar inoculated with bacteria and algae. Moreover, the culture of the older juveniles and adults did not thrive well, probably because manipulations with the fastgrowing prey had to be done regularly in order to maintain the cultures (Heip et al. 1978, p. 255-256).

Coomans \& Heyns' (1983) analysis of the action of the buccal cavity of Oncholaimus sahariensis upon food disagrees with those of Thun (1968) and Romeyn $\&$ Bouwman (1983). Coomans \& Heyns concluded that when labial muscles - inserting on the labial cuticle and on the walls of the buccal cavity - are contracted, they pull the lips backwards and bring the buccal capsule and tooth forward. However, it seems doubtful whether this action would bring the tooth out of the mouth opening to touch the food item (cf. illustration by Lorenzen 1969 on fixed specimens of the enchelidid Calyptronema maxweberi), My observations from sublateral and subventral views of the buccal cavity of e.g. Adoncholaimus thalassophygas (cited in Romeyn 1980), strongly indicate that the walls consist of at least 2 compartments and a sclerotization at the bottom. The posterior portion harbours the subventral 'tooth' (onchium) which I interprete as a sclerotization of the outlet of the salivary gland cell. The 'toath' is firmly anchored in the oesophageal musculature. The anterior portion is surrounded by a thin sheet of musculature usually not depicted in the literature. The actions of the buccal cavity could be described in the following simplified sequence: (1) detection of released DOM from the food item; (2) transverse expansion of the anterior portion of the buccal cavity; (3) contraction of the oesophageal musculature whereby 2 events are induced: (i) the walls of posterior portion of the buccal cavity glide telescopically along the inner side of the anterior portion so that the 'tooth' reaches outside the mouth opening, and (ii) at the same time the salivary gland cell contents empty and are injected into the food through the hollow 'tooth'; (4) the posterior portion glides backwards inducing a vacuum causing the buccal cavity to be filled with food which is passed into the oesophageal lumen (Fig. 3E, F).

The above hypothesis on the feeding habits and structure of the buccal cavity of oncholaimid and 
enchelidid nematodes is testable through TEM and histological-biochemical studies of the cuticularization of the buccal cavity as well as by chemical analysis of salivary secretions. It is supported by the conclusions of Meyers \& Hopper (1973), Riemann \& Schrage (1978) and Lopez et al. (1979) that the behaviour of the different oncholaimids studied did not reveal a predatory feeding strategy at all. The oncholaimids were attracted to organic matter in decaying plant material, showed gliding movements along e.g. cotton fibres, and released high amounts of mucus, agglutinating detritus particles from the surroundings. Also Pontonema vulgare were attracted to a dead shrimp which was ingested within a few hours (Rasmussen 1973. p. 54). A rather similar observation was made by Vranken (in Heip et al. 1985, p. 461) of Oncholaimus oxyuris accumulating and feeding on dead gastropods Hydrobia ulvae. The Danish biological consultant-firm Marin Idé provided me in 1981 with 0.251 jar almost filled with large $P$. vulgare. They were retained on a $500 \mu \mathrm{m}$ screen used to collect the macrofauna in the heavily organically polluted Mariager Fjord in Jylland. The successful domination by $P$. vulgare in that polluted sediment could be accounted for by the plentiful dead and dying animals. Stekhoven (1933a, b) noted some oncholaimids intensively feeding on bryozoans (cf. also observation by Menon 1973). The carnivorous nature of these nematodes does not conflict with the above hypothesis. The contents of the salivary glands will slowly dissolve the bryozoan after which the juice is ingested mouthful by mouthful, being found in the intestine in the form of feeding balls including also the gut contents of the bryozoan (Jensen 1979, Fig. 153.5). The above observations suggest that Wieser's classification of Oncholaimidae and Enchelidiidae as predators should be revised. Combining (1) the difficulties in rearing oncholaimids on living nematodes alone with (2) the ${ }^{14} \mathrm{C}$ experiments by Lopez et al. (1979) and (3) the above hypothesis, it appears most likely that these oncholaimids as juveniles feed on DOM, including exudates from bacteria and/or algae; older juveniles and adults may also feed on animals. Oncholaimidae and Enchelidiidae may properly be called the 'garbage collectors' among nematodes and the term scavengers would thus be the proper feeding group.

The proportion of juvenile oncholaimids and enchelidiids is high (>70\%) where they are abundant (in previous cited studies and in Jensen 1986). This aspect was completely overlooked when the presumed heavy predator pressure by these nematodes was previously discussed (Heip 1977, Smol et al. 1980). If subsequent studies support the above hypothesis and observations, then it makes no sense to compare, for example, the distribution patterns of oncholaimid with thoracostomopsid species. A discussion of the proportion of Group 2B compared to Wieser's other feeding groups also seems out of balance, since the consequence of the above discussion is that the proportion of nematodes with predatory feeding habits is much less than previously believed.

I therefore question whether predatory nematodes play an important role in regulating meiofauna densities or diversities. On the other hand, the role played by oncholaimids in stimulating bacterial and fungal metabolism in decomposition of organic matter on the sea bottom has largely been underestimated in the past and ignored in previous feeding schemes.

\section{Trans-epidermal uptake of DOM}

Direct evidence for DOM uptake among nematode species is provided by Chia \& Warwick (1969), Tietjen \& Lee (1975) and Lopez et al. (1979). However, I suspect that the species studied by these authors live in normally fully oxygenated habitats and that uptake is probably through oral ingestion. Montagna (1984) experimentally showed DOM uptake by a meiofauna community in which nematodes formed a major component. Although his study did not distinguish the types of nematodes utilizing DOM, the results proved direct meiofaunal uptake without bacterial involvement. Jensen (1986) suggested a trans-epidermal uptake among thiobiotic nematodes (mainly deposit feeders) dwelling in the microenvironmental gradient between oxic and anoxic processes and where microbial activity is high. The significantly higher body surface to body volume ratio in thiobiotic nematodes was viewed as an adaptation for DOM uptake from the environment and for respiration. From a view of resource partitioning Jensen (1986) found it very unlikely that a thiobiotic nematode dwelling in this potential source of food would not utilize it in the same way as is known from other marine benthic soft-bodied animals (review in Jørgensen 1976), mainly polychaetes (Stephens 1963, 1964, 1968, 1975, Jørgensen 1979, Jørgensen \& Kristensen 1980a, b). Organisms suggested to be solely dependent on DOM such as the gutless pogonophores (Southward \& Southward 1972, Southward 1982) and possibly also gutless oligochaetes (Giere et al. 1982) are known to utilize $\mathrm{CO}_{2}$ as a carbon source with the fixation of $\mathrm{CO}_{2}$ by the Calvin cycle intermediated through internal symbiotic chemoautotrophic bacteria (Southward et al. 1981, Felbeck et al. 1983). The significant release of primary amines from the neighbouring sediment along the burrows of the polychaetes Capitella capitata and Nereis diversicolor intermediated by their irrigation behaviour (Stephens 1975) might also explain the pre- 

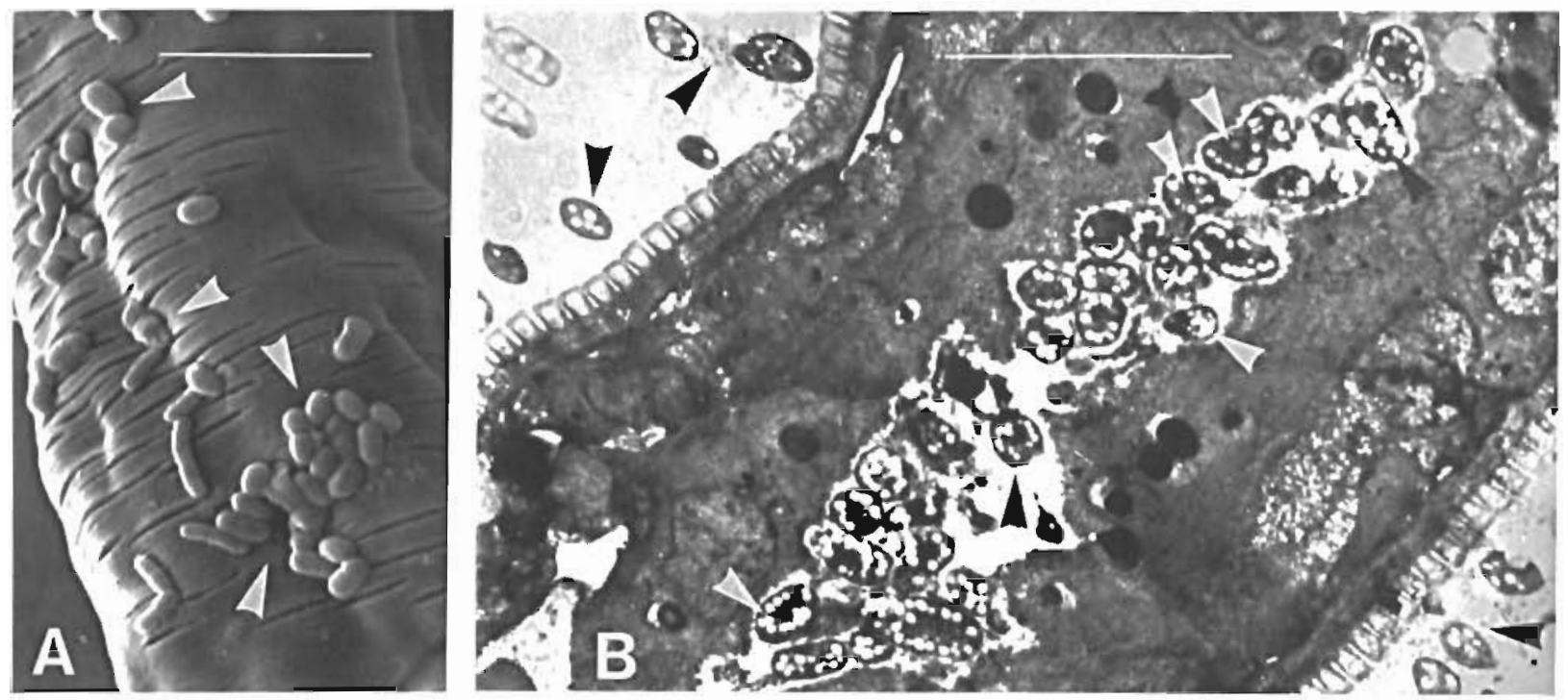

Fig. 4. Leptonemella aphanothecae with its symbiotic bacteria (arrows). (A) SEM photograph of cuticle. (B) TEM photograph through body showing bacteria on the cuticle and same undamaged bacteria in intestine. Originals in cooperation with $\mathrm{Dr}$ W Reichardt and Dr T Fenchel, respectively. Scale bars $=10 \mu \mathrm{m}$

sence of the very slender Spirinia sp. clinging around the tubes of the polychaete Sabella sp. (Jensen 1983b) as well as the presence of the extremely slender and gut-and-mouthless nematode Astomonema jenneri attached outside the tubes of the polychaete Onuphis jenneri (Ott et al. 1982). The thiobiotic species studied by Jensen $(1986,1987)$ have a mouth opening and all species have a gut, showing oral feeding; taking this all together indicates that differentiated mixotrophy takes place. I find no clear evidence from bright field microscopic observations that these species have internal procaryotic symbionts similar to those in Siphonolaimidae (Ott et al. 1982). Desmolaimoides thiobioticus and Filitonchoides thiobioticus (Jensen 1986) and Paralinhomoeus sp. (Jensen 1987) all have small globules in their body; TEM analyses and other ultrastructural techniques are, however, necessary in order to know more about 'foreign' inclusions in the nematode bodies and their possible relation to metabolism. There is no structural evidence that thiobiotic nematodes can utilize the energy in sulphide or of how they can avoid the toxic effect of sulphide from their surroundings. Wieser (1959), Hopper \& Cefalu (1973) and Ott et al. (1982) described different species of Stilbonematinae with external symbiotic bacteria Aphanothece and Schizothrix which are thought to trap and oxidize sulphide in the nematode Eubostrichus dianae and E. parasitiferus with the endproduct utilizable as an energy source (Powell et al. 1979). This is in contrast to Gerlach (1978) who suggested that Leptonemella aphanothecae feeds on its external bacteria (Fig. 4A, B), and provides good environmental conditions by migrating up and down between oxid and sulphide layers of the sediment (Ott \& Schiemer 1973, cited in Gerlach 1978).

\section{RESOURCE PARTITIONING}

Experimental evidence has shown that deposit and epistrate feeders discriminate between bacteria and unicellular algae, and among each type of food, select the proper size for ingestion (Tietjen \& Lee 1973, Alongi \& Tietjen 1980, Romeyn \& Bouwman 1983, Trotter \& Webster 1984). This primary discrimination of a diverse food source may allow 3 abundant deposit and epistrate feeders to coexist: Austranema mexicanum, Marylynnia punctata and Xyala oxybiotica (Fig. 1A to C) (Jensen 1986a). That study has also pointed out that food-size selection may effectively minimize interspecific competition; otherwise it is hard to explain how the 2 deposit feeders Desmolaimoides thiobioticus and Monhystera anoxybiotica can obtain their population maxima at the same place. Jensen $(1981,1983 b)$ showed that European congeneric Sabatieria species (deposit feeders) had different microhabitats in the sediments thereby minimizing interspecific competition. From faunistic information Schiemer (1984) concluded that the actual habitat selection of Caenorhabditis briggsae and Plectus palustris shows only weak overlap. This habitat separation agrees with observed differences in the food dependence of energetics and population parameters.

The co-existence of 2 pairs of closely related epistrate-feeding species Rhips anoxybiotica/Marylynnia 
johanseni and Euchromadora striata/M. preclara in a thiobiotic and an oxybiotic habitat respectively (Fig. 1A, B) might be explained by resuurce partitioning of a common food source made possible by their different buccal cavity structures. Rhips and Euchromadora species have moveable teeth close to the mouth opening, whereas Marylynnia species have one large tooth deep in the buccal cavity indicating different feeding behaviour (Jensen 1986).

\section{CONCLUSION}

Four feeding groups are recognized. Deposit feeders and epistrate feeders feed on bacteria and unicellular eucaryotes in different modes. Deposit-feeding species have no teeth and swallow the whole food undamaged (particulate feeders), whereas the epistrate-feeding species puncture the cell membrane with their teeth and ingest only the cell contents (juice feeders). Their considerable mobility, burrows and mucus secretion maintain more indirectly microbial populations near exponential state of growth. Thiobiotic species may even benefit from the intense microbial activity in the chemocline by obtaining food by uptake of DOM through the skin, hence supporting the idea that a differentiated mixotrophy takes place. Scavengers feed on dead animals or suck the cell contents of injured animals while releasing enzymes; these are placed in a separate group. Juvenile scavengers may take up DOM. Two types of predators are recognized by their equipment for catching or swallowing the whole prey. Resource partitioning in free-living aquatic nematodes is accomplished by food size, shape and quality selection and by means of differentiated structures in the buccal cavity.

Observations on actual feeding and histochemical studies of digestive enzymes in nematodes are scarce. Such studies, and better knowledge of grazing efficiency on specific microbes, will undoubtedly improve present understanding of nematode nutrition and their role in trophic dynamics.

Acknowledgements. Miss UIrike X. Windhövel kindly helped to improve my English.

\section{LITERATURE CITED}

Allgén, C. (1927). Freilebende marine Nematoden von der Küste Tasmaniens. Zool. Anz. 73: 197-217

Alongi, D. M., Tietjen, J. H. (1980). Population growth and trophic interactions among free-living marine nematodes. In: Tenore, K. R., Coull, B. C. (ed.) Marine benthic dynamics. Univ. South Carolina Press, Columbia, p. $151-166$

Baqri, Q., Baqri, S. Z. (1983). On the location of the oesophageal nuclei in the order Mononchida (Nematoda). Rec. zool. Surv. India 80: 341-354

Barsdate, R. J., Prentki, R. J., Fenchel, T (1974). Phosphorus cycle of model ecosystems: significance for decomposer food chain and effect of bacterial grazers. Oikos 25 239-251

Bongers, $T$ (1983). Bionomics and reproductive cycle of the nematode Leptosomatum bacillatum living in the sponge Halichondria panicea. Neth. J. Sea Res. 17: 39-46

Bonni, I. A., Mitchell, M. J. (1980). Role of nematode-bacterial interactions in heterotrophic systems with emphasis on sewage sludge decomposition. Oikos 35: 404-410

Boucher, G. (1973). Premières données écologiques sur les nématodes libres marins d'une station de vase côtière de Banyuls. Vie et Milieu 23: 69-100

Bouwman, L. A., Romeyn, K., Kremer, D. R., Es, F. B. (1984). Occurrence and feeding biology of some nematode species in estuarine aufwuchscommunities. Cah. Biol. mar. 25: $287-303$

Chia, F. S., Warwick, R. M. (1969). Assimilation of labelled glucose from seawater by marine nematodes. Nature, Lond. 224: 720-721

Coomans, A., Heyns, J. (1983). Oncholaimus sahariensis sp. n. from the Algerian Sahara. Hydrobiologia 107: 193-201

Cullen, D. J. (1973). Bioturbation of superficial marine sediments by interstitial meiobenthos. Nature, Lond. 242: 323-324

Deutsch, A. (1978). Gut structure and digestive physiology of two marine nematodes, Chromadora germanica (Bütschli, 1874) and Diplolaimella sp. Biol. Mar. biol. Lab., Woods Hole 155: 317-335

Felbeck, H., Liebezeit, R., Dawson, R., Giere, O. (1983). CO fixation in tissues of marine oligochaetes (Phalodrillus leukodermatus and $P$. planus) containing symbiotic, chemoautotrophic bacteria. Mar. Biol. 75: 187-191

Fenchel, T. (1970). Studies on the decomposition of organic detritus derived from the turtle grass, Thalassia testudinum. Limnol. Oceanogr. 15: 14-20

Fenchel, T., Harrison, P. (1976). The significance of bacterial grazing and mineral cycling for the decomposition of particulate detritus. In: Anderson, J. M., Macfayden, A. (ed.) The role of terrestrial and aquatic organisms in decomposition processes. Blackwell Scientific Publications, Oxford, p. 285-299

Findlay, S., Tenore, K. R. (1982). Effect of a free-living marine nematode (Diplolaimella chitwoodi) on detrital carbon mineralization. Mar. Ecol. Prog. Ser 8: 161-166

Gerlach, S. A. (1978). Food-chain relationships in subtidal silty sand marine sediments and the role of meiofauna in stimulating bacterial productivity. Oecologia (Berl.) 33: $55-69$

Giere, O., Liebezeit, G., Dawson, R. (1982). Habitat conditions and distribution pattern of the gutless oligochaete Phallodrillus leukodermatus. Mar. Ecol. Prog. Ser 8: 291-299

Gourbault, N,, Vincx, M. (1985). Nematodes abyssaux (campagne Walda du N/O 'Jean Charcot'). V Espèces nouvelles de Selachinematidae, dépourvues d'anus, Cah. Biol. mar. 26: 87-97

Grootaert, N., Maertens, D. (1976). Cultivation and life cycle of Mononchus aquaticus. Nematologica 22: 173-181

Heip, C. (1977). On the reproductive potentials in a brackish water meiobenthic community. Mikrofauna Meeresbod. 61: $105-112$

Heip, C., Smol, N. Absilis, V. (1978). Influence of tempera ture on the reproductive potential of Oncholaimus oxyuris (Nematoda: Oncholaimidae). Mar. Biol. 45: 255-260 
Heip, C., Vincx, M., Vranken, G. (1985). The ecology of marine nematodes. Oceanogr mar Biol. An. Rev. 23: $399-489$

Hopper, B. E., Cefalu, R. C. (1973). Free-living marine nematodes from Biscayne Bay, Florida. V Stilbonematinae: contributions to the taxonomy and morphology of the genus Eubostrichus Greef and related genera. Trans. Am. microsc. Soc. 94: 578-591

Jennings, J. B., Colam, J. B. (1970). Gut structure, digestive physiology and food storage in Pontonema vulgare (Nematoda: Enoplida). J. Zool., Lond. 161, 211-221

Jennings, J. B., Deutsch, A. (1975). Occurrence and possible adaptive significance of $\beta$-glucoronidase and arylamidase ('leucine aminopeptidase') activity in two species of marine nematodes. Comp. Biochem. Physiol. 52: 611-614

Jensen, P. (1979). Havbundens mikroskopiske dyreliv. In: Norrevang, A., Lunde, J. (ed.) Danmarks Natur. Havet. Politikens Forlag, København, p. 157-166

Jensen, P. (1981). Species, distribution and a microhabitat theory for marine mud dwelling Comesomatidae (Nematoda) in European waters. Cah. Biol. mar. 22: 231-241

Jensen, P. (1982). Diatom-feeding behaviour of the free-living marine nematode Chromadorita tenuis. Nematologica 28: $71-76$

Jensen, P. (1983a). Life history of the free-living marine nematode Chromadorita tenuis (Nematoda: Chromadorida). Nematologica 29: 335-345

Jensen, P. (1983b). Meiofaunal abundance and vertical zonation in a sublittoral soft bottom, with a test of the Haps corer. Mar. Biol. 74: 319-326

Jensen, P. (1986). Nematode fauna in the sulphide-rich brine seep and adjacent bottoms of the East Flower Garden, NW Gulf of Mexico. IV. Ecological aspects. Mar. Biol. 92: $489-503$

Jensen, P. (1987). Differences in microhabitat, abundance, biomass and body size between oxybiotic and thiobiotic free-living marine nematodes. Oecologia (Berl.) (in press)

Jorgensen, B. B. (1979). Bacterial sulfate reduction within reduced microniches of oxidized marine sediments. Mar Biol. 41. 7-17

Jorgensen, C. B. (1976). August Pütter, August Krogh, and the modern ideas of the use of dissolved organic matter in aquatic environments. Biol. Rev. 51: 291-328

Jergensen, N. O. .G., Kristensen, E. (1980a). Uptake of amino acids by three species of Nereis (Annelida: Polychaeta). I. Transport kinetics and net uptake from natural concentrations. Mar. Ecol. Prog. Ser. 3: 329-340

Jørgensen, N. O. G., Kristensen, E. (1980b). Uptake of amino acids by three species of Nereis (Annelida: Polychaeta). II. Effects of anaerobiosis. Mar. Ecol. Prog. Ser. 3: 341-346

Lopez, G., Riemann, F., Schrage, M. (1979). Feeding biology of the brackish water oncholaimid nematode Adoncholaimus thalassophygas. Mar. Biol. 54: 311-318

Lorenzen, S. (1969). Freilebende Meeresnematoden aus dem Schlickwatt und den Salzwiesen der Nordseeküste. Veröff. Inst. Meerestorsch. Bremerhaven 11: 195-238

Menon, N. R. (1973). A note on the occurrence of Pelagonema obtusicauda, a free-living nematode inside bryozoans. Helgoländer wiss. Meeresunters. 24: 170-172

Meyers, S. P., Hopper, B. E. (1973). Nematological-microbial interrelationships and estuarine biodegradative processes. In: Stevenson, L. M., Colwell, R. R. (ed.) Estuarine microbial ecology. Univ. South Carolina Press, Columbia, p. $484-489$

Meyers, S. P., Hopper, B. E., Cefalu, R. (1970). Ecological investigations of the marine nematode Metoncholaimus scissus. Mar. Biol. 6: 43-47

Montagna, P. A. (1984). Competition for dissolved glucose between meiobenthos and sediment microbes. J. exp. mar Biol. Ecol. 76: 177-190

Nielsen, C. O. (1949). Studies on the soil microfauna. II. The soil inhabiting nematodes. Natura jutl. 2: 1-132

Nuss, K. (1985). Ultrastrukturuntersuchungen zur Nahrungsabsorption von aquatischen Nematoden. Veröff. Inst Meeresforsch. Bremerhaven 21: 1-69

Ott, J. A., Rieger, G., Rieger, R., Enderes, F. (1982). New mouthless interstitial worms from the sulphide system: symbiosis with procaryotes. P.S.Z.N.I.: Mar. Ecol. 3: 31.3-333

Pamatmat, M. M., Findlay, S. (1983). Metabolism of microbes, nematodes, polychaetes, and their interactions in sediment, as detected by heat flow measurements. Mar. Ecol. Prog. Ser. 11: 31-38

Platt, H. M. (1977). Ecology of free-living marine nematodes from an intertidal sandflat in Strangford Lough, Northern Ireland. Estuar coast. mar. Sci. 5: 685-693

Powell, E. N., Crenshaw, M. A., Rieger, R. M. (1979). Adaptation to sulfide in the meiofauna of the sulfide system. I. ${ }^{35} \mathrm{~S}$-sulfide accumulation and the presence of a sulfide detoxification system. J. exp. Biol. Ecol. 37: 57-76

Rasmussen, E. (1973). Systematics and ecology of the Isefjord marine fauna. Ophelia 11 1-495 (1973)

Remmert, H. (1980). Ecology. Springer, Berlin

Riemann, F., Schrage, M. (1978). The mucus-trap hypothesis on feeding of aquatic nematodes and implications for biodegradation and sediment texture. Oecologia (Berl.) 34: $75-88$

Romeyn, K. (1980). Een inventarisatie van de nematoden fauna van de Dollard en de rol van diatomeën als voedsel voor enkele nematodensoorten. Boede Publ. en Versl. ? $1-40$

Romeyn, K., Bouwman, L. A. (1983). Food selection and consumption by estuarine nematodes. Hydrobiol. Bull. 17. 103-109

Romeyn, K., Bouwman, L. A., Admiraal, W. (1983). Ecology and cultivation of the herbivorous brackish-water nematode Eudiplogaster pararmatus. Mar. Ecol. Prog. Ser 12: $145-153$

Schiemer, F. (1984). Comparative aspects of food dependence and energetics of freeliving nematodes. Oikos $41: 32-42$

Smol, N., Heip, C., Govaert, M. (1980). The life cycle of Oncholaimus oxyuris (Nematoda) in its habitat. Annls Soc r. zool. Belg. 110:87-103

Southward, E. C. (1982). Bacterial symbionts in Pogonophora. J. mar. biol. Ass. U.K. 62:889-906

Southward, A. J., Southward, E. C. (1972). Observations on the role of dissolved organic compounds in the nutrition of benthic invertebrates. III. Uptake in relation to the organic content of the habitat. Sarsia 50:29-46

Southward, A. J., Southward, E. C., Dando, P. R., Rau, G. H., Felbeck, H., Flügel, H. (1981). Bacterial symbionts and low ${ }^{13} \mathrm{C} /{ }^{12} \mathrm{C}$ ratios in tissues of Pogonophora indicate unusual nutrition and metabolism. Nature, Lond. 293: $616-620$

Stekhoven, J. H. (1933a). Die Nahrung von Oncholaimus dujardini De Man. Zool. Anz. 101: 167-168

Stekhoven, J. H. (1933b). Bryozoan und Nematoden. Zool Anz. 105: 57-59

Stephens, G. C. (1963). Uptake of organic material by aquatic invertebrates. II. Accumulation of amino acids by the bamboo worm, Clymella torquata. Comp. Biochem. Physiol. 10: 191-202 
Stephens, G. C. (1964). Uptake of organic material by aquatic invertebrates. III. Uptake of glycine by brackish water annelids. Biol. Bull. mar. biol. Lab. Woods Hole 126: $150-162$

Stephens, G. C. (1968). Dissolved organic matter as a potential source of nutrition for marine organisms. Am. Zool. 8: 95-106

Stephens, G. C. (1975). Uptake of naturally occurring primary amines by marine annelids. Biol. Bull. mar. biol. Lab., Woods Hole 149: 397-407

Tenore, K. R., Tietjen, J. H., Lee, J. J. (1977). Effects of meiofauna on incorporation of aged eelgrass by the polychaete, Nephtys incisa. J. Fish. Res. Bd Can. 34: $563-567$

Thorne, G. (1927). The life history, habits and economic importance of some mononchs. J. Agric. Res. 34: 265

Thun, von, W. (1968). Autökologische Untersuchungen an freilebenden Nematoden des Brackwassers. Thesis, Kiel University

Tietjen, J. H. (1980). Microbial-meiofaunal interrelationships: A review. Microbiology: 335-338

Tietjen, J. H., Lee, J. J. (1973). Life history and feeding habits of the marine nematode Chromadora macrolaimoides Steiner. Oecologia (Berl.) 12: 303-314
Tietjen, J. H., Lee, J. J. (1975) Axenic culture and uptake of dissolved substance by the marine nematode, Rhabditis marina Bastian. Cah. Biol. mar. 16: 685-693

Trotter, D., Webster, J. M. (1984). Feeding preferences and seasonality of free-living marine nematodes inhabiting the kelp Macrocystis integrifolis. Mar. Ecol. Prog. Ser. 14: $151-157$

Warwick, R. M. (1981). Survival strategies of meiofauna. In Jones, N. V., Wolff, W. J. (ed.) Feeding and survival strategies of estuarine organisms. Plenum Press, New York, p. 39-52

Wieser, W. (1953). Die Beziehung zwischen Mundhöhlengestalt, Ernährungsweise und Vorkommen bei freilebenden marinen Nematoden. Ark. Zool. 4: 439-484

Wieser, W. (1959). Eine ungewöhnliche Assoziation zwischen Blaualgen und freilebenden marinen Nematoden. Osterr. bot. Z. 106: 81-87

Wieser, W. (1960). Benthic studies in Buzzards Bay. Il. The meiofauna. Limnol. Oceanogr. 5: 121-137

Wieser, W., Kanwisher, J. (1961). Ecological and physiological studies on marine nematodes from a salt marsh neas Woods Hole, Massachusetts. Limnol. Oceanogr. 6: $262-270$

This review was submitted to the editor; it was accepted for printing on November 11, 1986 